No. 6(63), 2019, pp. 65-79

https://doi.org/10.12797/Politeja.16.2019.63.04

\author{
Nataša JOVANOVIĆ AJZENHAMER (D) \\ University of Belgrade \\ natasa.jovanovic@f.bg.ac.rs
}

\author{
Haris DAJČ (D) \\ University of Belgrade \\ hdajc@f.bg.ac.rs
}

\title{
THE SERBIAN SOCIALIST PARTY \\ ATTITUDES TOWARDS THE EU \\ THROUGH THE LENS \\ OF PARTY PROGRAMMES
}

\section{BETWEEN PRAGMATISM AND PATRIOTISM ${ }^{1}$}

ABSTRACT In this paper, we will analyse the attitudes of the oldest political party in Serbia (the Socialist Party of Serbia - SPS) towards the European Union from the party's establishment to the present day. We have chosen this party for two important theoretical and methodological reasons. First, it is the only party in Serbia to inherit the continuity of socialist heritage, i.e. the only one to retain the socialist nomenclature when, at least nominally, party pluralism, an electoral regime and the transformation to capitalism began. The second reason is that the SPS is the largest left-wing party in Serbia, and one of the largest parties in Serbia in general. In this paper, we will apply a narrative analysis of the party's most important legal documents. The focus of our analysis will be on documents from 2010 and 2014, but to be able to follow the historical development of the attitudes of the SPS towards the EU, we have also included a document from 1990 in the analysis.

Key words: Serbia, Serbian Socialist Party, European Union, democracy, populism, nationalism 


\section{INTRODUCTION}

Accession to the European Union is one of the most important topics in contemporary Serbian society. Serbia has been in the EU accession process for ten years now and the $\mathrm{EU}$ is one of Serbia's main foreign policy coordinates despite the changes of parties in ruling positions. However, despite the relative consensus that Serbia should be a member of the EU, not all political actors support the idea of Serbia being on the "European path". It would be interesting and important to examine each Serbian party's attitude towards Serbia's EU accession, but we have chosen to analyse in this paper only the views of one party, the Socialist Party of Serbia (SPS).

There are several reasons why we have selected to analyse the SPS's attitudes towards the EU. The SPS is one of the largest parties in Serbia (and also the largest leftwing party in Serbia), ${ }^{2}$ and it has been part of the ruling regime for ten years, despite a shift of coalition partners in the government. In addition, the SPS is the only party to inherit the continuity of the socialist heritage and it is one of the oldest parties in Serbia. The SPS has stable voter support in elections and it is certainly an important factor in the Serbian political arena.

Therefore, the subject of our paper is the SPS's attitude towards Serbia's EU membership and Serbia's European orientation in general. The aim of our research is to analyse the nature of this relationship, and determine whether it is Europragmatism, Euroscepticism, Europhilia or Europhobia. The method we have used is the analysis of legal documents which spell out the basic and official SPS attitudes towards the EU. We have analysed the period when the SPS was founded (1990), and more recent documents (2010 and 2014). This is a comparative analysis of attitudes towards the EU since the party was founded to the present day, with the aim of creating a broader historical and political perspective. We have emphasised the analysis of the most recent documents as a starting point for the study of the SPS's views on the EU, but it was also necessary to include a brief overview of a document from 1990. In order to carry out a holistic study of the SPS's attitude towards the EU, other methods would need to be included in the analysis: interviews with party leaders, analysis of election campaign content, statements by party officials, etc. However, we believe that the analysis of legal documents is the first step that needs to be taken in order to conduct a more extensive study. This paper represents that first step.

It should be noted that the views of other political options in Serbia could also be analysed in this way. It should also be noted that the SPS does not represent the opinions of other political actors. However, this is an important research topic, and findings of our research may be useful to scholars in Serbia and other countries.

2 We will leave open the question of whether the SPS is of the left, centre, or some other political stripe. This may be the subject of analysis of another paper, but we will not delve into it here. The SPS has declared itself as left-wing, but this can certainly be re-examined and further analysed. 


\section{CONTEXTUAL FRAME: THE SPS IN THE TURMOIL OF SERBIA'S DEMOCRATISATION PROCESS}

The process of introducing a multi-party system and the shift from a command (planned) economy to a market economy in the space of ex-Yugoslavia, and especially Serbia, is characterised by several specificities. First, the collapse of socialism was accompanied by civil war. Second, the 1990s in Serbia were marked by international isolationism, which is particularly significant for the subject and the aim of this paper. Third, elections and a free market in Serbia were introduced only nominally - in reality, the former socialist nomenclature personified in a single party (SPS) retained its central position of power not only over the political and economic resources, but also over the reproduction of the system of values. Bearing that in mind, we can name the period from the end of socialism to the beginning of the $21^{\text {st }}$ century as a period of "blocked transformation". ${ }^{3}$ If we consider only the political arena, it is noticeable that party pluralism existed and that elections were held, but they were neither free nor fair because the ruling party used its dominant position for various election machinations. In other words, the 1990s in Serbia can be described as "electoral authoritarianism" with the existence of regular elections and party pluralism, which were merely a facade for various authoritarian content. ${ }^{4}$

The ruling party at the time was, as mentioned, the SPS. The SPS was founded in July 1990. The founding congress adopted the programme foundations and statutes that defined the SPS as a modern party of leftist orientation (as we said, nominally, it has remained a left-wing party in the contemporary context as well). ${ }^{5}$ The founding congress elected Slobodan Milošević as party president, and in December 1990, he won $65.34 \%$ of voters' support for the position of the President of Republic of Serbia. ${ }^{6}$ It was the beginning of a decade-long rule of the SPS, marked by circumstances including war, international sanctions, electoral machinations, political authoritarianism, and economic stagnation.

The beginning of the $21^{\text {st }}$ century has brought about major changes to the Serbian society. A civil revolt induced by electoral fraud in the autumn of 2000 resulted in a change of the ruling elite. After the fall of Slobodan Miloševićs regime in the autumn of 2000, the process of consolidation of democracy began, with unobstructed, free and fair elections, and the development of substantial multi-party dynamics (in particular, we can identify free and fair elections in 2003, thus we can analyse the minimal

M. Lazić, Čekajući kapitalizam, Beograd 2011.

$4 \quad$ W. Merkel, "Embedded and Defective Democracies", Democratization, vol. 11, no. 5 (2004), p. 38;

D. Pavlović, S. Antonić, Konsolidacija demokratskih ustanova u Srbiji posle 2000. godine, Beograd 2007, p. 45.

5 Istorija, at <https://www.sps.org.rs/istorija/>.

$6 \quad$ Izbori 1990. Konačni rezultati izbora za Predsednika Republike i narodne poslanike, Republički zavod za statistiku, 1991. 
level of consolidated democracy in Serbia). ${ }^{7}$ In parallel with institutional consolidation, a change in values was also recorded in the Serbian society.

After the October 5 changes, the democracy consolidation process (at the minimal level of democracy) and the normalisation of the neoliberal order at economic, political, and axiological levels had gradually begun. The overall social patterns and relations were adjusted towards unbindered profit production and the political sphere became pars pro toto of the whole, whose main goal was to enable unobstructed and free-functioning capitalism. On the other hand, the competitive principle spread from the economic sphere to the political one, and therefore electoral matches became a legitimate channel for recruiting protagonists for leading positions. ${ }^{8}$

Although in Serbia we cannot speak of consolidated liberal democracy, ${ }^{9}$ but rather of perpetuation of the democratisation process, certain democratic institutions, such as multipartyism, division of power, the rule of law, and liberal market principles became and have remained a framework for action of both political elites and citizens. In the process of democratisation of the Serbian society at multiple levels, the role of the SPS is especially interesting. After the breakdown of Slobodan Miloševićs regime, the SPS achieved the worst electoral results $\left(7.61 \%\right.$ in the 2003 elections, ${ }^{10}$ and $5.64 \%$ in the 2007 elections), ${ }^{11}$ but the party relatively quickly returned to the political scene as a strong and credible "player". In the 2012 general elections, the SPS won $14.51 \%$ of all votes $^{12}$ (in parliamentary elections in 2014 it won $13.49 \%,{ }^{13}$ and in parliamentary elections two years later only slightly less $-11.6 \%) .{ }^{14}$ Therefore, the SPS secured the relatively stable and not entirely insignificant support of Serbian voters. On the other hand, one important fact remains: in 2008 the SPS became a coalition partner in the

D. Pavlović, S. Antonić, Konsolidacija demokratskih ustanova u Srbiji posle 2000. godine, Beograd 2007, p. 45.

8 A. Birešev, N. Jovanović Ajzenhamer, “Autoritarni populizam: težak put do objašnjenja”, in B. Đorđević (ed.), Konstitucionalizam i ustavni dizajn u demokratskoj recesiji, Beograd 2018, p. 243.

9 Consolidated liberal democracy implies, apart from holding fair and free elections, a stable civil society and respect of civil rights, political freedom, horizontal accountability and effective power of an elected government. Few countries can meet all these criteria and be called a consolidated liberal democracy (W. Merkel, "Embedded and Defective Democracies", Democratization, vol. 11, no. 5 (2004), p. 37). In Serbia, the society is facing many challenges in the process of consolidation, and therefore it is difficult to talk about liberal democracy. We will not dwell on what these challenges and problems are, as it is not the subject of this paper.

10 Izbori za narodne poslanike Narodne skupštine Republike Srbije održani 28.12.2003, Republički zavod za statistiku Srbije, 2003, p. 42.

11 Parlamentarni izbori januar 2007. Republička izborna komisija, Republički zavod za statistiku Srbije, 2007.

12 Parlamentarni izbori 6. maj 2012. godine, Republička izborna komisija, Republički zavod za statistiku Srbije, 2012.

13 Parlamentarni izbori 16. mart 2014. godine, Republička izborna komisija, Republički zavod za statistiku Srbije, 2014.

14 Rezultati izbora za narodne poslanike Narodne skupštine Republike Srbije, održanih 24. aprila i 4. maja 2016. godine, Republička izborna Komisija, Republika Srbija, 2016. 
Serbian government and has remained that until today, despite the changes of governments (instead of the Democratic Party, since 2012, the Serbian Progressive Party is in power).

Therefore, the SPS is the party with the longest tradition in Serbia. It has inherited a socialist legacy (it still declares itself as a leftist political option); it managed to "survive" the downfall of the regime of its long-time leader and former president, Slobodan Milošević, and to establish itself in the democratic political scene of Serbia as a very important factor. Moreover, the only period it was not in power lasted only several years (if we consider the timeline 1990-2019). In addition, it should be noted that the leader of the party, Ivica Dačić, has held various positions (prime minister and minster), and this fact has certainly increased the popularity of the party. The SPS has more than 200,000 members and is one of the largest parties in Serbia. ${ }^{15}$

Keeping in mind all these important characteristics of the entire transition period, and the role of the SPS in Serbias history of transformation from socialism to democracy and capitalism, we can conclude that analysis of the SPS's attitudes towards different political and strategic topics is of significant importance to researchers. In this paper we analyse the SPS's attitudes towards the European future of Serbia, and its stance regarding Serbia's EU accession. This case study will reveal and illuminate one (important) piece of the political, both international and national, puzzle. The official website of the party states that the SPS is profiled as a modern state-building left party with social justice and democratic socialism as its programme foundations. The SPS is in favour of a market economy and social justice, privatisation of economy, democratisation of society, and integration of our country into the European Union. ${ }^{16}$ This quote already provides the answer to the question whether the SPS is a pro-European party - nominally, it is. Nevertheless, despite this affirmative answer, we will elaborate on the various characteristics of the SPS's stance towards the EU.

\section{SERBIA BETWEEN THE EAST AND THE WEST - THEORETICAL GUIDELINES}

EU accession is one of the most important strategic matters of Serbia, not only since the beginning of the $21^{\text {st }}$ century (when this issue actualised at a concrete, political level), it also became one of the prime topics immediately following the downfall of socialism. The direction of commitment (East or West) for all former socialist countries became one of the key topics following the collapse of the Berlin Wall. All Eastern European countries accepted the majority of principles immanent in the Western part of the world - first of all, they adopted capitalism and democracy, but the cultural, axiological and European identity orientation was not a constant factor in all the countries of the former Eastern bloc. A certain number of countries immediately began their EU

15 Istorija..., p. 9

16 Ibid. 
accession processes, but this was not the case with all former socialist countries. For some countries (like the Baltic countries, Poland, Czech Republic, Slovakia, Hungary, Slovenia and Croatia) the road towards the EU meant the so-called "return to the Western world", a return to the world of liberties, Christianity, abundance, and "escape from the shackles" of the USSR. ${ }^{17}$ On the other hand, some other countries of the Eastern bloc (Russia, Belarus and Ukraine) did not take the road towards the EU. Serbia, in line with the already mentioned specificities, is a unique case when it comes to the articulation of identities and policies between the West and the East.

The political identity of the EU is grouped, in broad terms, around three entities: participative democracy, the convergence between markets and social rights, and pacifism. ${ }^{18}$ Accession to the EU is not only a matter of daily politics, military concerns, or economics, but it is also a civilisational orientation that places societies on different ends of the East-West spectrum. If we consider this issue from the perspective of the Orientalist discourse, ${ }^{19} \mathrm{EU}$ membership is in a way a watershed between the Orient and the Occident, where the West is the symbol of progress, civilisation, modernity and development, and the Orient is the symbol of stagnancy, tradition, backwardness and patriarchy (as marked by the reductionist and essentialist Orientalist discourse) ${ }^{20}$ Regarding Serbia and the Balkans in general, this (Edward Said's) epistemological principle was shaped into its specific theoretical derivative embodied in the idea of Balkanisation, which as Marija Todorova, who coined the term, claims, includes a return to the tribal, barbaric, backward and primitive, even when considering the societies of the Old Continent. ${ }^{21}$

With all this in mind, it becomes clear that the topic of EU membership for Balkan countries (therefore Serbia as well) is a historical, political and identity problem that cannot be reduced to economic or tactical political orientation. In Serbia, the issue of joining the EU became a topic only after Milošević’s regime. The 1990s in Serbia were marked by international isolationism, while the 'opening' towards Europe implies convergence with electoral democracy consolidation. Therefore, the EU narrative and concrete steps towards membership arrived later than in the other post-socialist countries. In addition, it should be noted that in Serbia the issue of attitude towards the EU is more complex than in other (Balkan) countries. When we discuss Serbia's political orientation, we should also add into this theoretical and political equation the vector of Russia and the factor of continuity of close cooperation with it, in various aspects. In other words, since the beginning of the democracy consolidation at a minimal (electoral) level that occurred at the beginning of this century, Serbia has been in a specific position "between two fires" - between nurturing good relations with Russia and the pro-European orientation of the vast majority of the (ruling) political elite. In this

17 A. Kubiček, Evrofilija, evroskepticizam i evrofobija: diskursi o Evropskoj uniji tokom izbora u Srbiji 2012. godine, Beograd 2013, pp. 12-13.

18 T. Majer, Identitet Evrope: jedinstvena duša Evropske unije, Beograd 2009, p. 143.

19 E. Said, Orientalism, London 2003.

20 Ibid.

21 M. Todorova, Imaging the Balkans, Oxford-New York 2009, p. 3. 
paper we consider only the type and characteristics of the attitude of a single political protagonist towards the EU. Therefore, we will not analyse Serbia's position between Russia and the EU, although we believe it should be observed within the context of orientalisation of discourse in Serbia, as is the case with the relations between the West and Russia. ${ }^{22}$

As we have already explained, the issue of attitude towards the $\mathrm{EU}$ is very complex, and it cannot be regarded only through a formal legal aspect, or even through political directing or economic linking. It is essential to consider strategic positioning in the binary civilisational oppositions (East-West or Orient-Occident). The topics of proEuropean orientation, scepticism, and even the negative stance towards the EU, require further, detailed theoretical elaboration. However, since this is not the subject of this paper, we will only present a short theoretical model that includes Serbia's four basic views on the EU. These four attitudes towards the EU are the most common positions of political options in the Serbian society: Europhilia, which reflects general and constant support of the EU idea in a wider sense, and partiality towards its current practices; Europhobia, which reflects animosity towards the EU; Euroscepticism, which implies principal support to the EU with a critical approach to certain specific policies and practices; and finally, Europragmatism, which does not venture into the said civilisational debates about Serbia's links with the European identity and history, but rather regards EU membership as a way for Serbia to enjoy specific political and social benefits provided by the $\mathrm{EU}^{23}$

This theoretical framework will help us analyse the SPS's attitude towards the EU later in this paper. This theoretical introduction can be useful in analysing how Serbia's position on the European context is perceived by various political protagonists. However, in this paper we will focus on just one of longest lasting and most influential political options in Serbia. The following section of the paper analyses the main legal documents of the SPS, which will present us with a comparative analysis of attitudes towards the EU since the party was founded to today.

\section{ANALYSIS OF THE SPS'S POLITICAL PROGRAMMES}

For this research, we have used the 1990 and 2010 political programmes of the SPS, and the 2014 programme declaration. The analysis of the 1990 SPS programme and its European attitudes is not quite relevant for the $21^{\text {st }}$ century, but it is important for understanding the continuity in the party's pragmatic, inconsistent, and often contradictory attitudes towards Europe.

Even though it was founded in 1990, the Socialist Party of Serbia inherited the heritage of the Communist Party of Yugoslavia. This party has virtually ruled the region for

I. Nojman, Upotrebe drugog - “istok u formiranju” evropskog identiteta, Beograd 2011, pp. 85-86.

23 A. Kubiček, Evrofilija, evroskepticizam i evrofobija: diskursi o Evropskoj uniji tokom izbora u Srbiji 2012. godine, Beograd 2013, p. 4. 
decades (with a brief break from 2000 to 2008, when it was part of the opposition), and has been using the same name since its inception. Part of the credit for the popularity of this political option goes to the receptive performance of its leaders. In public appearances, they have glorified the lower classes of the population, and avoided anti-elitist views. Depending on their position, they divided the population into "honest people" and "corrupted elite". ${ }^{24}$ By comparing the populism of the current, descriptive and romanticised political programme of the party (enacted in 2010), with its more prosaic predecessor (1990), we analyzed messianic manipulative provisions, broadly set frameworks for programmatic determination, and the 'fusion' of one-party characteristics with quasi-political democracy. ${ }^{25}$ The 1990 political programme of the party is full of populist combinations of communist ideas from the past that the party did not renounce, and it showed the need for the alleged democratisation of the society. Although there are many topics that would be interesting to analyse, we will focus on the attitude towards the European Union in 2010 and 2014, and the European Community in the early 1990s.

If we take a look at the 1990 SPS programme, we can conclude that social justice is one of the favourite (populist) topics of the 1990s. Two major motifs of social justice in the 1990 SPS political programme were solidarity and social equality. Solidarity was reserved for the poor members of the society, so that they could be liberated from poverty, and gradually become equal with others. Social equality was perceived as a way of forming the same material, political and cultural opportunities for everyone. ${ }^{26}$ This is quite contradictory to the social reality of Serbia, one characterised by a shortage of elementary necessities of life and very low salaries. However, when considering the two-paragraph part of the programme that focused on Europe and international cooperation, we can observe that the aim of the party was to bring Yugoslavia into the European Community, but as an equal partner. It can also be observed that, by using the same logic of equality and mutual respect, they insisted on better cooperation with their neighbours in the region, other socialist countries, and "left and democratic powers" in Europe and the rest of the world. ${ }^{27}$ It is clear that the authors of the first SPS programme did not pay much attention to European integration, and they could not understand that the world had changed since the fall of the Berlin Wall in autumn 1989. The habit of being self-occupied without properly analysing the changes in the world and Europe becomes even more evident after reading the programme and decoding its contradictory character.

The SPS rule in Serbia since 1990 has been marked with wars, the second highest inflation in modern history, brain drain, and high migration rates. Slobodan Milošević lost the presidential elections in 2000 and, shortly afterwards, in spring 2001, he was charged

24 H. Dajč, N. Jovanović Ajzenhamer, N. Pantelić, "Socialist Party of Serbia: The Populist Chameleon", in M. Vasiljević, N. Jovanović Ajzenhamer (eds.), Contemporary Populism and its Political Consequences: Discourses and Practices in Central and South-Eastern Europe, Belgrade 2019, p. 15.

27 Ibid.

Програмске основе и статут Социјалистичке партије Србије, БеограА, 1990, р. 13.

Ibid., p. 40. 
with war crimes and stood trial in The Hague. Despite this, his party survived, and, after eight years in opposition, the SPS returned to power. Since then, as we have seen in the previous section of the paper, the SPS has had relatively stable voter support and has been participating in the work of the government despite changing coalition partners.

New circumstances, with European integration being high on the Serbian political agenda, resulted in some changes formulated in the 2010 SPS political programme. This programme is characterised by insufficient topic coverage, ambiguity, lack of solutions for most of its goals, disparity of content of various aspects, negligence of economic issues, and poor feasibility in general. The programme contained many goals that were hard to achieve. One of the goals was to build democratic socialism, so that Serbia could be a constitutionally democratic and socially responsible country. The other goals were consistent with the application of all human rights and freedoms, of standards of free and impartial information, and of public administration stripped of bureaucracy and politics. The programme goals concerning the people's initiative and referenda were relatively viable, since the SPS wanted people to be the decision makers, therefore we can label this as a rather populist idea of the framers of the programme.

The section of the new 2010 programme that covers the European future of Serbia did not encompass as much as would have been expected, considering that EU membership is an official policy goal of Serbia. What is more interesting, the section about the party's stance towards the EU was written in a very imprecise manner. It covers less than half a page of a 50-page document. The entire section of the SPS programme about the EU, Section 17: European Union, reads as follows:

The European orientation of the foreign policy of Serbia is based on the close relations of our country with the countries and nations of the European Union, with whom we share common historical and civilisational values and traditions, and common economic interests. The socialists believe that our country can and should contribute in building a common European home, and we therefore offer our full support and contribution to the negotiations regarding Serbia's European Union membership. The elements of European politics on which we have based our actions are:

- Striving to achieve open borders in Europe, and the free movement of people, goods, capital and ideas.

- Supporting the process of Serbia's accession to the European Union.

- Harmonising Serbia's political, economic and social system with European Union legislation and standards.

- Respecting human rights and freedoms conventions adopted within the UN, Council of Europe and other international organisations.

- Respecting the borders of the Republic of Serbia confirmed by valid international agreements in compliance with OSCE principles. ${ }^{28}$

The presented elements of the programme regarding European politics are clear and Europhilic, but special attention should be paid to the last two items, as they come as a conclusion to the previous three items, which will be analysed later. The policy included

28 Програм Сочијалистичке партије Србије, БеограА, 2010, р. 24-25. 
both Serbia's European Union accession and Kosovo within the borders of Serbia. This was the official policy of the governments of which the SPS was part. For the SPS, it was important to paint a portrait of itself as a pro-European party in one of its most important party documents. However, in the rest of the programme, excluding Section 17, there is no mention of the EU, its politics, or the harmonisation of the Serbian system with EU legislation and standards. It should be noted that most Serbian parties are pro-European - not all of them, of course, but most of them are. The SPS's views on the EU do not deviate from the main political position that Serbia belongs in the European Union.

The phrase 'common European home' denotes that the EU is observed as an organisation similar to a home or a family. That description sent a clear message why it was worth being part of such a project - it represents a family where opportunities for work, employment and assistance are possible. The programme makers stress that Serbia can and should contribute to the process of building this common European home.

To understand fully the attitude of the SPS towards the EU, it is necessary to analyse the other parts of the programme focused on international relations, security policy, etc.

In Section 14: Security and Neutrality Policy, the SPS analysed the Serbian stance towards the NATO and Serbia's Euro-Atlantic integration, where, at the end of a long self-apologetic text, it "gave" the people the final decision through a "democratic referendum" ${ }^{29}$ This stance was one of the most important political results of Koštunica's first, government (2004-2007), which even put "military neutrality" in the Constitution of the Republic of Serbia in 2006. The socialists supported his government, although they were not part of it, and they adopted the same logic towards Euro-Atlantic integration.

In Section 15: International Position of Serbia, the programme starts with a description of the difficult position Serbia was in and the need to preserve sovereignty and territorial integrity, and of its exposure to numerous political, economic and territorial impositions..$^{30}$ The programme makers portrayed themselves as leaders capable of finding a compromise that would help Serbia escape from its difficult situation, through implementing its constructive and sensitive policy. ${ }^{31}$ This populist rhetoric is common for some of the Serbian political elites. They balanced between a nationalistic and a Europhilic narrative. Section 15 is a perfect example of the SPS's stance on Europe and of its inconsistencies in respecting European values and pragmatism, very selectively applying what it (the SPS) needed:

Historically and civilisationally, not only geographically, Serbia is a European country and a European society. Serbia's orientation towards European integration stems from its logical endeavour to lessen pressures, confirm and revitalise the European identity of a state-building free nation. Choosing the European Union does not mean shutting ourselves out of mutually beneficial relations with others. The world is polycentric. Empowering ourselves for partnership should stabilise and widen our horizons towards prosperity.

\footnotetext{
29 Ibid., pp. 22-23.

30 Ibid., p. 23.

31 Ibid.
} 
The socialists believe that Serbia should choose cooperation instead of obedience. Dignity instead of defiance and spite. Sobriety instead of romanticism. Self-respect instead of self-loathing. Respect of its values without arrogance towards the values of others. Culture of dialogue instead offorce. These are the principles that we will follow in order to prevail and win our place in the community of free nations. They are the foundation of the awareness that there is a clear line under which we cannot and will not go in order to accept demands, no matter who they come from, in order to defend the territorial integrity and sovereignty of the country. ${ }^{32}$

The oblique argumentation at the beginning of the passage is obviously filled with Europhilic attitudes. The Serbs are already a part of the union simply due to the fact that they have a free country; they only need to confirm their identity and further increase their international prestige. It might look like a Europhilic discourse at the beginning, but after analysing the last part of the cited paragraph, it seems like a part of another document or a part of a programme taken over from another, somewhat less Europhilic, party. This last part highlights a line they will not cross no matter who demands it. It is very clear that the SPS took over the same mantra that other populist parties of the decade embraced: I Kosovo i Evropa (Both Kosovo and Europe). ${ }^{33}$ This conclusion created a very useful populist motto for the SPS, which they have particularly applied in their foreign policy, where their presence has been the strongest among the key state ministries since 2008. As we have said, this is the dominant foreign policy position of most parties in Serbia, and the SPS is no different from the rest. The balance between safeguarding national interests and joining the EU is constant political rhetoric of most political actors in Serbia and is considered a 'winning ticket' in elections.

Section 16: Foreign Policy - Peace and Cooperation Policy of the programme looks like a manifesto from the time of the Cold War, when Yugoslavia was among the most prominent leaders of the Non-Aligned Movement. The authors of the programme stressed the need for cooperation with all "countries and nations of the world", and "the great powers" (USA, the BRIC countries, Latin America and the Arab world), for the renewal of active participation in the Non-Aligned Movement, and for cooperation in the region. ${ }^{34}$ This part of the programme remained more descriptive and important than Section 17: European Union. It is a clear sign that a path towards the EU was important to the SPS, but still it is seen only as a wider part of Serbia's relations with the rest of the world and Europe.

The 2014 programme declaration, The Vision of Serbia 2020, was adopted as the newest SPS programme at the party's Ninth Congress in December 2014. ${ }^{35}$ The section once clearly titled European Union in the 2010 programme has been renamed Serbia's European Path. This is relevant for several reasons:

32 Ibid., p. 24.

33 This famous slogan was very popular in the early 2000s and was embraced by the DSS, the DS, the SPS, and the SNS - all of these parties formed governments in Serbia since the downfall of Milošević in 2000.

34 Програм Соиијалистичке партије Србије, БеограА, 2010, p. 24.

35 Програмска декларащија визија Србије 2020, БеограА, 2014. 
a. Glorification of the President of the SPS, Ivica Dačić, as the person responsible for the visa liberalisation for Serbian citizens in 2008, and for Serbia becoming an EU candidate country in 2012;36

b. Although the authors stress the full support for all 35 chapters in the accession process, they clearly state that this process should respect the "strategic national interests of Serbia". These strategic national interests are explained in a very vague manner, stressing the need for mutual respect, and the global positioning of Serbia as one who fought on the "good side" in World Wars I and II; ${ }^{37}$

c. The longest part of the 4-page section is dedicated to foreign policy and security, where the authors stress the need for Serbia to stay open to other influences and cooperation (with BRIC and other non-EU states). This part becomes crucial when the authors start mentioning the importance of Serbia being an observer within the Collective Security Treaty Organization, and the Russian-Serbian Humanitarian Centre for emergency situations. The authors connected the Serbian path to the EU with its political neutrality and stated that any change of political neutrality should be accepted only as a result of a decision made by the citizens of Serbia through a national referendum (the old mantra from Koštunica's first government)..$^{38}$

When comparing the 2010 and 2014 programmes, not much progress can be observed regarding the party's European attitudes. The biggest change is even more confusion. While the 2010 programme dedicated an entire section to the EU, the authors of the 2014 programme declaration moved it to a section that was even more confusing, where the EU process was connected to Serbian strategic national interests, foreign policy, cooperation with Russia and other non-EU countries, and the ultimate importance of remaining a militarily neutral country. The authors of the 2014 document tried even less to hide the idea that European progress is possible, but only if Serbia can remain neutral and keep its relations with other countries without committing itself to European foreign and security policies.

Another major characteristic of the SPS's political programmes of 2010 and 2014 was its descriptiveness and elusiveness of a concrete idea. Unlike the 1990 political programme that was much more compact, and contained specific political ideas - such as diverging from communism, and accepting or combining with a new democratised system in certain segments - the new 50- and 100-page programmes had little specific to say. Even though the party had allegedly given up on the communist rhetoric, and it allegedly advocated a planned economy, it was aware that it appealed to followers of the communist idea, so it advocated the abolishment of the rule of capital over labour. ${ }^{39}$ Moreover, despite their marked support for EU accession, for being a member of the European family, the socialists made quasi-conditions aimed at protecting dignity.

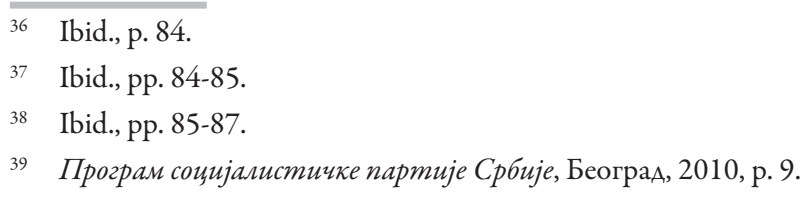


Namely, they stated that the international position of Serbia should be built with dignity, not out of defiance and spite, and preference was given to practicality over romanticism. This vague stance changed very clearly in the latest 2014 programme, in the section related to the European path, cooperation with the Collective Security Treaty Organization, and the Russian-Serbian Humanitarian Centre, and where the definition of "strategic national interests" was introduced.

\section{CONCLUSION}

The views of any Serbian political party on Serbia's accession to the EU is a complex topic that requires a triangulation of methods in order to obtain a comprehensive and complete answer to the question of whether a particular party represents a Europhilic or a Eurosceptic view. As we have said, interviews and content analysis should be included in a holistic analysis of attitudes towards Europe, but one of the basic methods and first steps that scholars should certainly take is to analyse legal documents. This paper has taken that first step: we have analysed the SPS's views on the EU in two major legal documents, the 2010 programme and the 2014 programme declaration. We have also made a brief review of the 1990 programme, although the different context in which it lies should be taken into consideration, and therefore it cannot be fully compared with the other two programmes. Nevertheless, it was necessary to make a historical overview in order to highlight certain continuities that exist in the SPS programmes. Given that the SPS is one of the oldest parties in Serbia, it was necessary to take a 'look back' and thus gain insight into the continuities and discontinuities of the foreign policy positions of this party.

Our analysis showed that, even though 10 years had passed since the publishing of the first and the second programme, and even though Serbia has taken some important steps along its European path, it is clear after analysing the most important legal documents of the most long-lived party in Serbia that the SPS shows no clear inclination towards joining the EU. Hence, even though in the actual programme of the party Serbia's EU future is among the highest priorities, the legacy of the old SPS from the 1990s, and the political pragmatism that balances between their populist-nationalist ideas and their EU promise to the electorate still prevail. The results of that policy are mostly visible in Serbia's undefined position regarding its foreign policy and its compliance with EU policy.

Despite the presence of Europhilic elements in the SPS's legal documents (such as ideas about belonging to a European family, etc.), we still believe that the SPS's attitudes towards the EU are more Europragmatic than Europhilic. The SPS's programmes are not a detailed strategy for Serbia's EU accession, and the idea of Europe is part of a broader ideological, populist platform that embraces a wide range of desirable ideas, such as national sovereignty, EU accession, social justice, etc., which is the case with most political options in Serbia in general. Therefore, we believe that the SPS's view that Serbia should be a member of the EU is a Europragmatic strategy, especially when 
taking into consideration its more recent 2010 and 2014 programmes. More precisely, in the latest 2014 programme, in the section about the European path, we can find topics about cooperation with the Collective Security Treaty Organization and the Russian-Serbian Humanitarian Centre, and a definition of "strategic national interests". This finding shows that for the SPS Serbia's accession to the EU is one of the foreign policy strategies that fits into the general narrative of the need to maintain good relations with all foreign policy partners.

As we have already pointed out, this kind of rhetoric, which implies a balance between different foreign political forces and the need to protect national interests (especially territorial integrity), is the most common one on the Serbian political scene. The SPS is no exception. It is a very successful mantra that secures votes. In this context, although there are Europhilic elements in the analysis of the SPS 2010 and 2014 programmes, its relationship with the EU is only a part of a pragmatic, and obviously very successful, political strategy. In Serbia, only a small number of parties take a "pure" Europhilic or Europhobic position. The SPS is part of the corps of parties oriented towards Europragmatism.

It should be emphasised once again that we have conducted an analysis of the main legal documents, and that other sources of data (campaign analysis, statements of party leaders, interviews with party members and leaders, etc.) should be included in order to conduct more detailed research. Only by combining these methods could we obtain a complete and holistic picture of the SPS's attitude towards the EU. Therefore, our research represents only a starting point for future research. This could also be applied to other parties in Serbia, which would be interesting to analyse in this way as well.

\section{BIBLIOGRAPHY}

Birešev A., Jovanović Ajzenhamer N., "Autoritarni populizam: težak put do objašnjenja", in B. Đorđević (ed.), Konstitucionalizam i ustavni dizajn u demokratskoj recesiji, Beograd 2018.

Dajč H., Jovanović Ajzenhamer N., Pantelić N.. "Socialist Party of Serbia: The Populist Chameleon", in M. Vasiljević, N. Jovanović Ajzenhamer (eds.), Contemporary Populism and Its Political Consequences: Discourses and Practices in Central and South-Eastern Europe, Belgrade 2019.

Istorija, at <https://www.sps.org.rs/istorija/>, 15 December 2019.

Izbori 1990. "Konačni rezultati izbora za Predsednika Republike i narodne poslanike", Republički zavod za statistiku, 1991.

Izbori za narodne poslanike Narodne skupštine Republike Srbije održani 28.12.2003, Republički zavod za statistiku Srbije, 2003.

Kubiček A., Evrofilija, evroskepticizam i evrofobija: diskursio Evropskoj uniji tokom izbora u Srbiji 2012. godine, Beograd 2013.

Lazić M., Čekajući kapitalizam, Beograd 2011.

Majer T., Identitet Evrope: jedinstvena duša Evropske unije, Beograd 2009. 
Merkel W., “Embedded and Defective Democracies”, Democratization, vol. 11, no. 5 (2004), https://doi.org/10.1080=13510340412331304598.

Nojman I. Upotrebe drugog - “istok u formiranju” evropskog identiteta, Beograd 2011.

Parlamentarni izbori januar 2007. Republička izborna komisija, Republički zavod za statistiku Srbije, 2007.

Parlamentarni izbori 6. maj 2012. godine, Republička izborna komisija, Republički zavod za statistiku Srbije, 2012.

Parlamentarni izbori 16. mart 2014. godine, Republička izborna komisija, Republički zavod za statistiku Srbije, 2014.

Pavlović D, Antonić S., Konsolidacija demokratskih ustanova u Srbiji posle 2000. godine, Beograd 2007.

Program at <https://www.sps.org.rs/documents/PROGRAM\%20SPS.pdf>, 15 December 2019.

Rezultati izbora za narodne poslanike Narodne skupštine Republike Srbije, održanih 24. aprila i 4. maja 2016. godine, Republička izborna Komisija, Republika Srbija, 2016.

Said E., Orientalism, London 2003.

Todorova M., Imaging the Balkans, Oxford-New York 2009.

Програмске основе и статут Социјахистичке партије Србије, БеограА, 1990.

Програм социјалистичке партије Србије, БеограА, 2010.

Програмска декмарација визија Србије 2020, БеограА, 2014.

Nataša JOVANOVIĆ AJZENHAMER - PhD. Sociologist. Teaching Assistant at the Department of Sociology, Faculty of Philosophy, University of Belgrade, where she has been working since 2016. Her research focus is on Classical Sociological Theory and Religious Studies. Currently working as a researcher at the Populist Rebellion against Modernity (Poprebel) H2020 project.

Haris DAJČ - PhD. Historian, Assistant Professor at the Department of History, Faculty of Philosophy, University of Belgrade, where he has been working since 2009. His research focus is on Modern and Contemporary History. Haris Dajč is a scientist in charge of two H2020 projects at the Faculty of Philosophy, University of Belgrade: Populist Rebellion against Modernity (Poprebel) and Delayed Transformational Fatigue in Central and Eastern Europe: Responding to the Rise of Illiberalism/Populism (Fatigue). 